a posthumous pardon. In the Gateshead case, he had refused to permit the commemoration as a martyr of a catholic priest executed for treason. He considered his previous judgment 'too restrictive and less than charitable', particularly given recent improvements in ecumenical relations. He had not taken into account that the calendar of festivals in the Church of England commemorates such figures as Thomas More and John Fisher alongside the protestant martyrs of the age. The faculty was granted. [WA]

doi:10.1017/So956618Xo9002129

\title{
Re St Andrew, Bainton
}

York Consistory Court: Hill Dep Ch, August 2008

Churchyard - bench - objections

The rector, churchwarden and PCC secretary applied for a faculty to introduce an iron bench into the churchyard extension in memory of a teenager buried there. The DAC offered no objection. A resident of a neighbouring property objected by letter but did not seek to become a party opponent. The deputy chancellor dismissed each of her objections, which included a concern that the provision of a bench would encourage more criminal behaviour in the area, that the bench was of poor workmanship, that the land might be needed for future burials, that another location had first been considered and rejected, and that the family concerned did not attend church. He concurred with the DAC's judgment that the proposed bench would not detract from the character of the Grade I listed building. The faculty was granted until further order, with the particular caveat that, if the objector's fears about the attraction of 'undesirables with a criminal intent' came to be realised, then the faculty could be set aside and the bench ordered to be removed. [WA]

\section{Re St Andrew, Kildwick}

Bradford Consistory Court: Walford Ch, October 2008 Re-ordering - funding - economic conditions

The petitioners sought a faculty for a major re-ordering of the Grade I listed church. The proposals were broadly supported by the DAC, the amenity societies and the district council. There was considerable local opposition. The chancellor noted that the scheme had been devised at a time of 'wholly different 